\title{
Pornography Behavior of Junior High School Student
}

\author{
Rika Hardani*) $^{1}$, Dwi Hastuti ${ }^{2}$, Lilik Noor Yuliati ${ }^{3}$ \\ ${ }^{1}$ Sinar Muslim Sejati Indonesia Foundation, Tangerang Selatan, Indonesia \\ ${ }^{2,3}$ Departement of Family and Consumer Sciences, Faculty of Human Ecology, \\ Bogor Agricultural University \\ Bogor, 16680, Indonesia \\ "Corresponding author: rikaheru97@gmail.com
}

\begin{abstract}
The purpose of this research is to identify the behavior of pornography Junior High School students namely the behavior viewed pornographic web, read books or comics which contain pictures of porn sites, heard or said these things pornographic, think about the things that related to pornography. This research also wanted to know the factors that encourage children to perform the behavior of pornography and see whether there are differences in the behavior of pornography among the boys and girls. We use the cross-sectional studies as a research design. The Participant who is used is 600 children, 278 boys and the girls 322 from two national secondary schools and two private schools in the South Tangerang. The results of the study showed that the behavior of pornography on the boys and girls, in some of the items the question, there is a significant difference in statistic. The question namely viewed pornographic web every day, game play pornographic, pleads the girlfriend over the phone, forced a friend to see the pornographic movie, imagine scenes of pornographic sites when playing. Some of the factors that encourage the behavior of pornography on children is the use of the internet through handphone, amount of pocket money, spare time children after the return of schools and the influence of a friend.
\end{abstract}

Keywords : pornography behavior, junior high school student, internet influence

Abstrak. Tujuan penelitian adalah untuk mengidentifikasi perilaku pornografi siswa SMP yaitu perilaku melihat web porno, membaca buku atau komik yang mengandung gambar-gambar porno, mendengar atau mengatakan hal-hal porno, memikirkan hal-hal yang berkaitan dengan pornografi. Penelitian ini juga ingin mengetahui faktor yang mendorong anak untuk melakukan perilaku pornografi serta melihat apakah ada perbedaan perilaku pornografi antara anak laki-laki dan perempuan. Desain penelitian yang digunakan adalah cross-sectional studi. Partisipan yang digunakan adalah 600 anak, 278 anak laki-laki dan 322 anak perempuan yang berasal dari dua sekolah menengah pertama negeri dan dua sekolah swasta di wilayah Tangerang Selatan. Hasil penelitian menunjukkan bahwa perilaku pornografi pada anak laki-laki dan perempuan pada beberapa item pertanyaan menunjukkan adanya perbedaan yang signifikan secara statistic. 
Pertanyaan tersebut yaitu melihat web porno setiap hari, bermain game porno, merayu pacar lewat telpon, dipaksa teman melihat film porno, membayangkan adegan porno saat sedang bermain. Beberapa factor pendorong perilaku pornografi yaitu penggunaan internet melalui handphone, banyaknya uang saku, waktu luang yang dimiliki anak setelah pulang sekolah, dan pengaruh teman.

Kata kunci: perilaku pornografi, siswa Sekolah Menengah Pertama, pengaruh internet

\section{Introduction}

Pornography is one of negative behavior. According to the dictionary Indonesia, pornography (sometimes abbreviated as "pornography," "prON," or "pornography") is a description of the human body or the behavior of human sexuality openly (explicitly) with the purpose of arousing interest in the lusts ( sexual abuse). Pornography is also specified as reading material that is deliberately and solely designed to arouse sexual desire for sex. The emergence of the pornography this behavior correlation between the value of the value of the desire to see pornography with preoccupation pornography, sexual history, compulsive use of the internet and search for the sensation of Kraus and Rosenbergh (2014).

The behavior of pornography must be monitored since the beginning, because the behavior of pornography initially lightweight, can be developed into a more serious behavior. Further consequences of view pornography (pornographicaction, consuming the whore, behavior asexual beings, abuse children). The behavior of watching pornography, if left in the long term and frequency increased, will can cause various problems to the behavior of teenagers. The problems that can arise because of the high intensity of watching pornography including free sex, sexual violence, decrease the academic achievements, drug addiction pornography, sexual orientation disorders (Luder et al, 2011). If not stopped or handled immediately, it can cause incorrect behavior is even worse as sexual violence sexual orientation that turn aside, romantic life as an adult who is not fun even can be fatal as murderer sexual desire is not satisfied and distorted (D'orlando 2011). According to data published by KPAI (2015), from 2011 until 2014 , the number of child victims of pornography and evil online in Indonesia has reached the number of 1,022 persons children. In detail, children accessing the online porn site 20 percent, 15 percent object pornographic cd and the children of victims of sexual violence online 11 percent. The number of is predicted to continue to increase if not handled optimally. The more the number of the children of victims of crime online growing along with the increasing number of internet users in the country.

Technology advances very rapidly occur in various areas. The industry, machine, communications and various other fields, brought many changes in the community. The changes occur gives many positive effects, but there is also a negative impact on the community. Negative things that cause the development of technology such as internet use excessive force on children. Easier access to content pornography clearly gives the impact that is felt. Based on a survey conducted by the National Commission for the Protection of Children (2011) in 12 big cities in Indonesia about the behavior of teenagers, found 83 percent 
teenagers never confess watch video porn sites, 93,7 percent do sexual relationship and 21 percent or one of the five young people in Indonesia have been doing abortion. The material spectacle pornography is easily obtained by children from comics online and offline. This time internet users in Indonesia as much as 88,1 million men and 50 percent adolescents (APJII 2014). The number of internet users as much as 74 percent lived in urban areas and the surrounding area.

Some of the previous study in Indonesia about the behavior of pornography has highlighted the progress of technology as the main reason as the cause of this condition. Research on the identification of the behavior of pornography difficult found. Research has done more on the consequences of the behavior of pornography as free sex among teenagers, behavior asexual beings and so on. The identification of the early behavior of pornography can be used as prevention efforts to prevent behavior lead to a more severe level.

The purpose of this research is to identify the behavior of pornography Junior High School students namely the behavior viewed pornographic web, read books or comics which contain pictures of porn sites, heard or said these things pornographic, think about the things that related to pornography. This research also wanted to know the factors that encourage children to perform the behavior of pornography and see whether there are differences in the behavior of pornography among the boys and girls.

Participants is junior high school age children because in this stage the children have high curiosity and always want to try something new. The criteria for junior high students from the condition of the different school hours and students of different economic background that can describe the various conditions of the students

\section{Methods}

This research is done with the use of cross-sectional research method, research done at one time and certain place. The election of the participant is done in four Secondary Schools in South Tangerang City. The participant is taken in this research is a junior secondary school-age children because of the age of the junior high school student is in stage that have a high curiosity. The location of the research done in Tangerang south of the selected by purposive sampling because South Tangerang is the urban areas, buffer zone capital city. The inhabitants of the city on the edge of the Jakarta there are many peoples who work in the capital city or other cities around Jakarta. This urban areas, including South Tangerang, is a very high internet users. Schools are used as a research location selected by purposive sampling based on the recommendation of the Department of Education in South Tangerang City by criteria for junior high students from the condition of the different school hours and students of different economic background that can describe the various conditions of the students. Then the school has obtained, random done with the technique of Cluster Random Sampling with the class as a cluster, to ease in loading data.

The total population of the four schools is 750 children, participants who qualify is 278 boys and 322 girls. Data collection is done with charging the 
questionnaire by the participant. The questionnaire used for behavioral Data Pornography using questionnaires Behavior Pornography Teenagers who compiled by the author with the value of the Alpha Cronbach 0.70, with likert scale $1-3(1=$ never $2=$ rarely $3=$ often $)$.

The data obtained is processed first through the editing process, coding, scoring, data entry, data cleaning and data analysis using Microsoft Excel and SPSS for windows. The analysis used is descriptive analysis (value of average Standard deviation, minimum value and maximum value). T-test that different used to see whether there is a difference between pornography on boys and girls.

\section{Findings}

\section{Characteristic}

The results of this research showed that the age of the participants is 13 years and 14 years. This age is the stage which children become the beginning of adolescence (Santrock 2011). This period is the time that it is difficult for children because many changes occur on themself. Physical changes often make the children feel anxious and irritable. They need to make their problems and search for certainty of his identity.

Most of the participants $(40,4 \%)$ is the first child with two siblings (41.9\%). Participants who only have one brother, often feel lonely in the house. The existence of a friend in the school can reduce loneliness. Nearly half of the participants $(45.7 \%)$ have a total of 5 friends. When entering the age of the early teens, children are very interested to play in groups and form groups of friends. There are many different types of groups of friends. In general, there is a group of friends that is based on the same interest, similarities in physical condition, similarities in the social and economic conditions, etc. In this research, most of the reasons for friendship is common hobbies and interest $(51.7 \%)$.

The election of four schools which are generally different from the background, cause this research describes the condition of the different participants. Seen from the facility owned by participants, show its diversity. The amount of pocket money vary from less than $\mathrm{Rp} 25,000$, - up to Rp 100.000, every week. This means that the participants can spend around $\mathrm{Rp} 5,000$, - up to Rp 25,000, -. The schools that the students have a good economic family, the food in the canteen is usually more expensive. In the school cafeteria the price of food

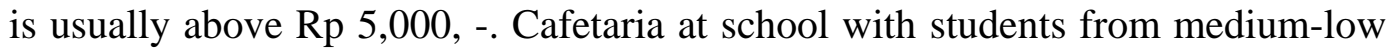
economic family, usually food also is cheaper. With Rp 500, - food is still can be purchased.

The amount of pocket money that acquired a child every week, sometimes there is no rest. The use of the remaining pocket money in various participants. The Participant that put the remaining money pocket there are as many as 60,7 percent. As much as 15.5 percent of participants who use the remaining pocket money to save money and buy internet connection package. Participants use the remaining money only to buy internet pulse as much as 10.6 percent.

Another facility owned by the participants is the type of electronic device (gadgetry). Most of the participants have one electronic device $(57.5 \%)$ and most are handphone $(52.2 \%)$. Now, it is very common to see students bring 
handphone. Not only in the school with students have the middle-top economic family status, but in schools where the average students have family with socioeconomic status of medium and low, they also seems to have a handphone. The quality of handphone is easily used to gain access to the internet. The handphone with the price that is not too expensive, can be used to reach out to the internet. The results of the study showed that the participants can use the internet connection package $(54.1 \%)$ with the cost to buy it obtained from pocket money $(44.1 \%)$ or given by the parents $(43,1 \%)$. Most of the participants get internet access from the house $(68.1 \%)$ and internet access in a day also vary. As much as 37,4 percent participants access the internet for 1-3 hours / day as much as 20.8 percent view the internet for 4-5 hours / day and as many as 14,8 percent of participants see the internet for more than 8 hours / day.

\section{Pornographic Behavior}

The behavior of pornography children identified from some aspects such as view pornographic content online and offline, speak or hear things pornography, motivation early pornography, reason to do so, the time spent in a day to view the contents of the pornography and the possibility of addiction pornography. Participants who choose number 1, shows that the participants do not do something as in question. Answer choice 2 and 3 can be interpreted that the participant has done the behavior of pornography, rarely or often.

The behavior of pornography online form in the questionnaire with questions: "I open web site porn sites every day"; I play games that have scenes that shows the body which intimate "'; I see the film vulgar on the internet at least $3 \mathrm{x}$ in the last month ". The behavior of pornography offline known by questions like:" I forced by friends to read comics pornographic " ; I invite your friends to read the comics pornographic ".

The more advanced communication technology, in this case the internet, it is very likely that things can be known with fast. The types of pornography online commonly accessed by the participant for example porn sites, gaming, movies vulgar. The type of porn offline seen for example is comics pornographic. As much as 76.6 percent boys and girls 94,4 percent participants expressed never see pornographic web every day.

The form of the question to know whether participants said or heard these things pornographic for example with the question: "I appeal boyfriends/girlfriend by phone or skype"; "I chat with friends about pornographic scene in comics". The behavior of pornography in the form of said these things soured or pornography on the types of opponents is also a question. As much as 19.5 percent participants, pleaded boyfriends/girlfriend by phone or skype. The participants also discussed about pornography with friends (16.1\%). For the children of secondary schools, pornography is interesting. At this time, they wanted to know more about the new things. For example, discuss about porn sites with friends, as much as 18.8 percent of boys and girls by $13.9 \%$. Originally the participant want to know pornography, there are as much as 23 percent of boys and 22 percent of girls do so voluntarily, boys (18.4\%) and girls (20.1\%) invited friends to see things pornographic. There are also forced by friends as much as 24.9 percent of boys and girls 20.1 percent. 
Furthermore the reasons or factors that encourage participants to perform the behavior of pornography is diverse. Childrens's free time can also affect the children to engage in the behavior of pornography. The amount of freetime children can be caused by schools hours more quickly than other schools. The national school usually finish more quick. As much as 27 percent of the participant uses his spare time to play the game pornographic. The length of time spent on the children to perform the behavior pornography, vary. The boy had seen some porn site every day is 23.4 percent, while the girls of 5.3 percent. Participants who watch the films vulgar on the internet at least 3 times in the last month is 30.2 percent of boys and 25.7 per cent of girls never do so. The participants who want to open some porn site every night there are 32,4 percent boys and 28,8 percent of girls who have felt this. The participants who saw the game porn sites for 2 hours a day there is 38,6 percent, and see some porn site for less than one hour every day there are as much as 23.2 percent. This must be monitored, because one of the signs of addiction pornography is the duration of the view content pornography in a week. According to Cooper et al. (1999), that view content pornography more than 11 hours / last week is one of the characteristics of exposure pornography. If in the daily children saw the content pornography during 2 hours, then in a week about 14 hours a child view content pornography. Emotional condition junior high school age students are often not sure, sometimes annoyed, sometimes angry, sometimes sad also. This is because there are many hormonal changes in the body that will be developed into a more mature (Santrock 2011). Emotional condition participants also can be a factor causes the behavior of pornography. As much as 20 percent of participants said often see some porn site when it is upset. When combined total, there are as many as 73,2 percent of participants who have seen some porn site when it is angry. So there is also a net cash consumption as much as per cent of the participants who had never playing the game porn sites when it is upset. This research also wanted to see in general the possibility of addiction pornography on the participant. Forms of the question is: "I felt angry when forbidden to see the film pornographic"; "I feel happy playing the game porn sites"; "When I was busy working on school tasks, i very want to see some porn"; "When I learned in the classroom, I really want to open the porn sites"; "On when I play with friends type opponents, I imagine pornographic scenes in film". The results of this research showed the participant 24.1 percent feel angry when forbidden. The condition of addiction a matter is the desire to continue to get the content pornography, feel stress if not get it and reduce restraint in its use (Grubbs et al, 2014). The results of this research as much as 15.4 percent boys replied that when playing with the the girls, imagine scenes of porn sites in the film.

This research showed that there is a significant difference $(p<0.05)$ behavior of pornography on boys and girls in response to some questions. (See table). The results of the study showed that the behavior of pornography on the boys turned out to be higher than the girls. Previous research has examined the cause of pornography on children and adolescents in advance of technology (internet) and facilities that received by children. Research Karina dkk. (2014) stated that the characteristics of the family also affects the behavior of teenagers. Family Income related negative characters teenage girl (Karina et al. 2014). 
Families who are high the economy condition will be easier to provide more focus on children as providing more electronic devices or more pocket money. The results of this research also shows the relationship of constructive contributions significantly on the number of electronic devices owned by the children of $(\mathrm{R}=$ $0,130 * *)$, the amount of pocket money $(\mathrm{R}=0,136 * *)$, internet access that the length of each day $(\mathrm{R}=0,142 * *)$ with the behavior of pornography children. Seems more the electronic media is owned by the children, the behavior pornography children will tend to increase. The number of the electronic media owned, children will more easily also access the internet. To increase the amount of pocket money, will also make the children more easily and long access the internet. The longer the children access the internet, behavior pornography also tend to increase .

Table 1 Distribution of pornographic behavior statements and significant test results by gender

\begin{tabular}{|c|c|c|c|c|c|c|c|c|}
\hline \multirow[t]{2}{*}{ No } & \multirow[t]{2}{*}{ Statements } & \multicolumn{3}{|c|}{ Boy $(\%)$} & \multicolumn{3}{|c|}{$\operatorname{Girl}(\%)$} & \multirow{2}{*}{ p-value } \\
\hline & & Never & Rarely & Often & Never & Rarely & Often & \\
\hline 1 & view porn sites every day & 76.6 & 23 & 0.4 & 94.4 & 53 & 0 & $0.000^{* *}$ \\
\hline 2 & playing porn games & 82 & 17 & 1.1 & 96.3 & 3.4 & 0 & $0.000 * *$ \\
\hline 3 & $\begin{array}{l}\text { seduce girlfriend/boyfriend) } \\
\text { by phone }\end{array}$ & 73.7 & 23 & 2.9 & 86.1 & 12 & 1.5 & $0.000^{* *}$ \\
\hline 4 & $\begin{array}{l}\text { forced by friends to see porn } \\
\text { movies }\end{array}$ & 75.2 & 21 & 4 & 83.6 & 15 & 0.9 & $0.002 * *$ \\
\hline 5 & $\begin{array}{l}\text { when playing imagine porn } \\
\text { scenes }\end{array}$ & 84.5 & 14 & 1.4 & 96.9 & 2.5 & 0.3 & $0.000^{* *}$ \\
\hline
\end{tabular}

\section{Discussion}

The behavior of pornography children examined from several aspects such as view pornographic content online and offline, speak or hear things pornography, motivation early pornography, reason to do so, the time spent in a day to view the contents of the pornography and may drug addiction pornography.

Teenagers, especially those who aged 13 and 14 years, consume more pornography (Sabine et al. 2008). Children and adolescents are very vulnerable to the material pornography. In a study in Italy, almost all men and two-thirds of the teenage girl has been exposed to the material pornography (Romito and Beltramini 2015). The behavior of pornography has occurred among adolescents the age of Junior and Senior High School (Weber et al, 2012), around the age of 12-15 years period is the identity search (Erickson 1964). The results of this research shows the type of porn online commonly accessed by participants including porn sites, games, film vulgar.

The type of porn offline viewed by the participants is comics pornographic. The behavior of pornography in the form of said these things soured or pornographic sites on the types of opponents also done by participants such as appeals boyfriends/girlfriend by phone or skype. The other type of 
behavior pornography is discuss abbout pornographic with friends. For the children of secondary school age, pornography is interesting. At this time, they want to know more about the new things. Initially the participants want to know pornography, some do so voluntarily. The great curiosity, will be able to encourage them to do the behavior of pornography, as seen spectacle pornographic materials that can bring the lusts (Seto et al 2015.) further research results from the initial motivation to perform the behavior pornography invited friends or friends force. This is in line with the research done Mobarake et.al. (2014) that there is a significant positive relationship between friendship and antisocial behavior. This means that the higher the ties of friendship that does not benefit, the higher the anti-social behavior. From the results of research and Beltramini Romito (2015) also known reason to view pornography that curious, there are those who ask about pornography, information about sex, because love it, because sex is something interesting.

Another reason is shown from the results of research about the reasons for an example of the behavior of pornography is a state upset emotional. When the participants feel upset, they will see some porn site or playing games pornographic. Emotional condition for the early teens must become the main concern for parents and teachers. Most of the participants have family with a small number of. The children who have only one brother (brethren men or women), often feel lonely in the house. Loneliness is the cause of the sons of mate in schools. The existence of a friend in the school can reduce loneliness. Nearly half of the participants have 5 friends. The existence of a friend at this age is very important. The children who do not get a friend at this age usually will feel marginal and isolated. The election of a good friend is very important. A good friend, will have a positive impact on the academic and social development of children (Williams and Anthony 2015). The school as a place for the children to spend most of their time, also plays an important role in the development of their children. There are many different types of friend group. In general, there is a group of friends that is based on the same interest, similarities in physical condition, similarities in the economic and social conditions etc. In this study, most of the reasons for friendship is interest and hobby together.

The condition of the participants in this research is relatively diverse. The facility is owned by the participants also vary. There are participants who have enough money, there is also a little. The amount of pocket money that acquired a child every week, sometimes no rest. The use of the remaining pocket money is different in children, there are also some who used to buy the internet package. The factors that affect pornogarfi including age, gender men and women, ethnic, socio-economic status, family values (Rivera et al. 2016). The amount of pocket money for children, allows children to always be able to meet the needs of the internet (buy packages subscribe). Information and communication technology has changed the way people communicate and consume, because they have easy access to learn new things, depending on gender and socio-economic status they (Mascheroni and Ólafsson 2015). Based on the relationship between the economic and social status of the consumption of pornography, has shown that adolescents from families with social status higher economic uses material pornography more often (Luder et al. 2011). According to Shahidul and Karim (2015), that a positive 
school environment will have a positive impact on children also. A good school will make rules to regulate the students not to bring telephone to schools. According to research Mariani and Bachtiar (2010) that media that most often used to view the contents of the pornography is a handphone.

The results of this research showed that the participant can access the Internet using the internet subscription package with the cost to buy it obtained from pocket money or given by the parents in addition to the pocket money. Internet access in Indonesia is now easier and cheaper. So that teenagers will be easier to access content pornography through the internet. The condition of the family also affects the children in accessing the internet. Parents who perform regular monitoring of the activities of children will be able to reduce the consumption of pornography through the internet. The use of the computer that is consistent (more than 10 hours / week) is associated with the consumption of pornography (Mattebo et al. 2013). The Increasing ease of access to the internet today, also affects the behavior of pornography community, especially teenagers (Owens et al. 2012). The phenomenon of pornography is one of which is the result of the rapid development of technology such as internet (Seto 2010). Plus so many ease that is accepted by the children, even the majority of the facilities from their own parents (Weber et al. 2012). Easy access (Romito and Beltramini 2015) pornography content in social media through gadgetry (HP, video, internet) obtained at an early age without given the rules of the use of the right can be one of the causes of the behavior of pornography. This technology explosion has resulted in the growth in the experience in the virtual world and in some cases involving the risk of consuming or involved voluntarily interact with porn site (Livingstone et al. 2014). From the results of research and Beltramini Romito 2015), as much as 89 percent men and 39 per cent of women said seeing things pornography. In between respondents who expose most of the use of media: video (86.6 percent of boys and 66.6 percent women); male magazine (81,3 percent sons and 60 percent of women); see pornography online (66.5 per cent). Then found as many as 67,3 percent sons and 54 percent of women see pornography from blackberry.

The number of spare time the children are also very responsible for causing the behavior of pornography. The result shows that there are participants using the time reaffirming to watch pornographic movies or playing games revolving pornographic. The school rule about the length of school hours can also affect pornography children. From the four schools that function as the location of the research, there are schools that have hours learn more short. Learning hours started from the morning until 12 day. Public schools generally have hours learn more shorter than private schools, it may cause the participants have more spare time. This is in line with the research Holt et al. (2012), there are three additional variables related to cyberdeviance who spent time online outside of school hours, have more computer skills and have the computer in a special place (not common area in the house).

This research also want to see in general the possibility of addiction pornography on the participants. Some signs of the condition of the addiction of a thing is the feeling angry when will do so, always feel like to do so at any time, or when we see something then that reflected are the things that make them addicted (Hilton \& Watts 2011). The results of this research showed that many participants 
who had never felt angry when forbidden to see the film pornographic. There are participants who have never felt the spirit when not playing the game porn sites. The answer to that need to be taken seriously is also when playing with opponents, type children imagine pornographic scene in the film. The behavior of pornography while still in mind, must be handled to be eliminated. If you think negative, will be able to continue to level in more severe and can be done real. According to Rothman \& Adhia 2016, Adolescent Dating Abuse (ADA) that victimisation associated with the use of pornography more often, view pornography, asked to perform the sexual acts that first partner see in pornography, and watch pornography during or after the use of marijuana. Dave et al (1995) shows that the consumption of describing sexual activities without violence increase aggressive behavior.

\section{Conclusion and Recommendation}

\section{Conclusion}

The behavior of pornography that is done by the participant in the form of pornography online, offline, through conversation and imagine things pornographic. The advance of technology bring great changes in various areas of life including in the development of communications and internet. This change in addition to bring the positive values for the progress of the nation, also brought negative impact. Pornography is one of the negative effects of the advance of technology. Some of the factors that encourage the behavior of pornography on children is the use of the internet through handphone, many pocket money, spare time children after the return of schools and the influence of a friend.

The behavior of pornography must be allerted early, because it will bring bad effect for the young generation. The condition of the family, friends and schools have a great influence in the development of their children. The amount of spare time that belongs to children, will tend to make the children have filled it with seeing things pornographic. Easy access to the internet is supported by handphone facility owned by the children made the children to see the things that are not good. The remaining pocket money can be used to purchase internet package. Some point behavior pornography done by more boys.

\section{Recommendation}

At this age, the role of parents and teachers are very good to be able to guide the children to not fall into the behavior of pornography. Regular monitoring of the parents to accompany the children to spend time to spare them must be the main priority for the parents in the house. The provision of assessment and other facilities, must consider the readiness of children in choosing which should be done that are not. The results of the study showed that the behavior of pornography on the boys is higher than the girls.

Some suggestions for schools and parents to implement some of this program in the daily life in an effort to prevent pornography children:

1. Parents play an important role in childrearing. Parents must try to take advantage of the time to meet with the sons of effectively and efficiently. Create a routine activity program every week to perform an intimate and fun 
activities with the children, for example swim together, or go to the park with the children. Parents involve children in making the program weekly family.

2. Give a lot of physical activity to children, especially boys, so that his mind no chance to think about porn.

3. The school provide many extracurricular activities after school, so that children can take advantage of their free time.

4. The school held a childrearing activities held on Saturday or Sunday to be followed by the parents. This program must be made routinely once a month. The parents also need to increase their knowledge about childrearing with reading many articles education of children. Create a target for example one day, an article education - one day one the article.

5. Parents limit the amount of pocket money and electronic facilities in children.

6. The Ministry of Education needs to perform an orderly and careful examination on the books used in teaching in schools, both printed and electronic devices. Do not let the book called as teaching, contains material content pornography or other negative behavior.

7. The Ministry of information can create a more stringent regulations related to web site content, both in the form of games or movies. The penalty for the punishment for the creator of the web pages that contain content pornography must be dealt with decisively.

8. The process of recruitment of teachers and employees more selective so that all teachers and employees in the schools will be able to provide a good character and positive behavior in schools. Routine training teachers about the knowledge to educate children routinely done at least once a month.

9. Create strict rules about bringing the handphone to schools. Handphone (HP) was allowed to be brought into the school is a simple Handphome that can only be contacted parents and not HP that can be used to access the internet. The students are allowed to bring HP this type must also believe the school every morning before starting the lesson. The schools provide the box in the classroom to take HP every morning.

10. Make regular program about sex education in schools, for example once one semester once. Source selection and right materials in accordance with the age and developmental stage. A resource person to be an expert in the field of education of children.

\section{References}

[APJII] Assosiasi Pengguna Jaringan Internet Indonesia. (2014). Data Pengakses Internet di Indonesia. https://www.apjii.or.id/

Beyens, I., Vandenbosch, L., Eggermont, S. (2014). Early Adolescent Boys'Exposure to Internet Pornography: Relationships to Pubertal Timing, Sensation Seeking,and Academic Performance. The Journal of Early Adolescence. doi: 10. 1177/ 0272431614548069

D'orlando, F. (2011). The demand for pornography. Journal of Happiness Studies, 12(1), 51-7. doi:http://dx.doi.org/10.1007/s10902-009-9175-0

Holt, T.J,, Bossler, A.M., May, D.C. (2012). Low self-control, deviant peer associations, and juvenile cyberdeviance. American Journal of Criminal 
Justice :AJCJ, 37(3), 378-395. doi:http://dx.doi.org/10.1007/s12103-0119117-3

Hilton, D., Watts, C. (2011). Pornography addiction: A neuroscience perspective. Surgical Neurology International, 2, 19. http : // doi.org / 10. 4103/2152-7806.76977

[KNPA] Komisi Nasional Perlindungan Anak. (2011). Data Perilaku Remaja. https://www.merdeka.com/komisi-nasional-perlindungan-anak/

[KPAI] Komisi Perlindungan Anak Indonesia. 2015. Kejahatan Online. http://www.kpai.go.id

Kementrian Agama RI. Undang-Undang Pornografi. http://www.kemenag.go.id/.

Kraus, S., Rosenberg, H. (2014). The pornography craving questionnaire: Psychometric properties.Archives of Sexual Behavior, 43(3), 451-62. Doi : http : // dx . doi. org/ 10. 1007 / s10508-013-0229-3

Livingstone, S., Mason, J. (2015). Sexual rights and sexual risks among youth online: a review of existing knowledge regarding children and young people's developing sexuality in relation to new media environments. http ://eprints.lse.ac.uk/64567/1/Livingstone_Review_on_Sexual_rights_and_ sexual_risks_among_online_youth_Author_2015.pdf

Luder, M,, Pittet, I., Berchtold, A., Akré, C, Michaud, P., Surís, J. (2011). Associations between online pornography and sexual behavio adolescents: Myth or reality? Archives of Sexual Behavior, 40(5), 1027-35. doi : http://dx.doi.org/10.1007/s10508-010-9714-0

Mascheroni, G., Ólafsson, K. (2015) . The mobile Internet: Access, use, opportunities

and divides among European children. New Media \& Society, 1461444814567986.

Mattebo, M. (2014). Use of pornography and its associations with sexual experiences, lifestyles and health among adolescents. Journal of developmental and behavioral pediatrics: JDBP34(7) · DOI: 10.1097/ DBP. 0b013e31829c44a2 - Source:

Mariani, A., Bachtiar, I. (2010). Keterpaparan Materi Pornografi dan Perilaku Seksual Siswa Sekolah Menengah Pertama Negeri. Jurnal Makara, Sosial Humaniora, 14(2), 83-90.

Mayer, F., Arent, T., Geserick, G., Grundmann, C., Lockemann, U., Riepert, T., Ritz-timme, S. (2014). Age estimation based on pictures and videos presumably showing child or youth pornography. International Journal of Legal Medicine, 128(4), 649-52. doi:http://dx.doi.org/10.1007/s00414014-1012-2

Mike, A., Dave, D., Keri, B. (1995). A Meta-Analysis Summarizing the Effects of Pornography II: Aggression After Exposure. Human Communication Research, Volume 22,

Mobarake, R.K., Juhari, R., Yaacob, S.N., Esmaeili, N.S. (2014). The moderating role of self-control in the relationship between peer affiliation and adolescents antisocial behavior in tehran, iran. Asian Social Science, 10(9), 71-81. ISSN 1911-2017 E-ISSN 1911-2025 .URL: http://dx.doi.org/10.5539/ass.v10n9p71 
Owens, E.W., Behun, R.J., Manning, J.C., Reid, R.C. (2012). The impact of Internet pornography on adolescents: A review of the research.Sexual Addiction \& Compulsivity, 19(1-2), 99-122.

Romito, P., Beltramini, L. (2015). Factors associated with exposure to violent or degrading pornography among high school students. The Journal of School Nursing, 31(4), 280-290. doi: http : // dx. Doi .org / 10.1177/ 1059840514563313

Rivera, R., Santos, D., Cabrera, V., Docal, M. (2016). Online and offline pornography consumption in colombian Adolescents. Comunicar, 24(46), 37-45. doi:http://dx.doi.org/10.3916/C46-2016-04

Rothman, E.F., Adhia, A. (2016). Adolescent Pornography Use and Dating Violence among a Sample of Primarily Black and Hispanic, UrbanResiding, Underage Youth. Behavioral Sciences, 6(1), 1. http://doi.org/10.3390/bs6010001

Sabina, C., Wolak, J., Finkelhor, D. (2008). The nature and dynamics of Internet pornography exposure for youth. CyberPsychology \& Behavior, 11(6), 691-693.

Santrock, J.W. (2011). Life-Span Development: Thirteenth Edition. New York: McGraw-Hill.

Seto, M.C. (2010). Child pornography use and internet solicitation in the diagnosis pedophilia. Archives Sexual Behavior. 39(3). doi : http : // dx.doi.org/10.1007/s10508-010-9603-6

Seto, M.C., Hermann, C.A., Kjellgren, C., Priebe, G., Svedin, C.G., Långström, N. (2015). Viewing child pornography: Prevalence and correlates in a representative community sample of young swedish men. Archives of Sexual Behavior, 44(1), 67-79. doi:http://dx.doi.org/10.1007/s10508-0130244-4

Shahidul, S.M., Karim, A.H. (2015). Intergenerational Bonding in Family and School Contexts: Which Does Impact More on Degree Aspiration of Students?. Asian Social Science; Vol. 11, No. 27; 2015 .ISSN 1911-2017 E-ISSN 1911-2025 .Published by Canadian Center of Science and Education. Doi : 10.5539/ass.v11n27p63 URL: http : // dx. doi. Org / 10 $.5539 /$ ass.v11n27p63

Weber, M., Quiring, O., Daschmann, G. (2012). Peers, parents and pornography: Exploring adolescents' exposure to sexually explicit material and its developmental correlates. Sexuality \& Culture, 16(4), 408-427. doi:http://dx.doi.org/10.1007/s12119-012-9132-7

Williams, L.R., Anthony, E.K. (2015). A model of positive family and peer relationships on adolescent functioning. Journal of Child and Family Studies, 24(3), 658-667. doi:http://dx.doi.org/10.1007/s10826-013-9876-1

Wolak, J., Finkelhor, D., Mitchel, K. (2011). Sexual Abuse: A Journal of Research and Treatment23(1) 22-42 (C) The Author(s) 2011 Reprints and permission:http://www.sagepub.com/jurnalsPermissions.nav.DOI:10.1177/ 1079063210 72143.http://sajrt.sagepubcom

Wolfe, S.E., Marcum, C.D., Higgins, G.E., Ricketts, M.L.(2014). Routine Cell Phone Activity and Exposure to Sext Messages Extending the Generality of Routine Activity Theory and Exploring the Etiology of a Risky Teenage Behavior. Crime \& Delinquency, 0011128714541192. 